\title{
Kompozit Levhalar için Ankastre-Tip Eğilmeli, Çok Numuneli Yorulma Test Makinesinin Geliştirilmesi
}

\author{
Development of Fixed-End Type, multi-Sample Flexural Fatique Test Systems for \\ Composite Plates
}

\author{
H. Ersen BALCIOĞLU ${ }^{* 1, a}$, Raif SAKİN ${ }^{2, b}$, Akif Birol DUMANAY ${ }^{3, c}$, Halit GÜN ${ }^{1, d}$ \\ ${ }^{I}$ Makine Mühendisliği Bölümü, Mühendislik Fakültesi, Ușak Üniversitesi, Ușak, TÜRKiYE \\ ${ }^{2}$ Makine ve Metal Teknolojileri Bölümü, Edremit MYO, Ballkesir Üniversitesi, Balıesir, TÜRKIYE \\ ${ }^{3}$ Bilgisayar Teknolojileri Bölümü, Edremit MYO, Ballkesir Üniversitesi, Ballkesir, TÜRKIYE
}

• Geliş tarihi / Received: 07.04.2017 • • Düzeltilerek geliş tarihi / Received in revised form: 30.07.2017 • Kabul tarihi / Accepted: 02.08.2017

\begin{abstract}
$\ddot{O} z$
Bu çalışmada, fiber takviyeli kompozit levhalar, ahşap levhalar, plastik esaslı levhalar ve hafif metalik levhaların eğilmeli yorulma davranışlarını karakterize eden özgün bir yorulma test makinesi geliştirilmiştir. Geliştirilen özel bilgisayar yazılımı ile kontrol edilebilen ankastre-tip eğilmeli test makinesi, yorulma testi için deplasman kontrol metodunu kullanmaktadır. Yorulma testleri uzun süren mekanik testlerdendir. Geliştirilen test makinesi aynı anda 10 numuneyi test edebilme özelliği sayesinde zamandan ve enerjiden tasarruf edilebilmektedir. Yazılım ara yüzü üzerinden yapılacak basit veri girişleri ile farklı sehim oranları $(\mathrm{R})$ ve $0.1-10 \mathrm{~Hz}$ frekans altında yorulma testleri yapılabilmektedir. Her bir numune için test zamanı, test frekansı, eğme kuvveti, rijitlik kaybı, yük tekrar sayısı gibi parametreler hem yazılım ara yüzünden hem de internet üzerinden izlenebilmektedir ve müdahale edilebilmektedir. Numunelerinden herhangi biri hasara uğradığında araştırmacının e-postasına uyarı mesajı ve ilgili test verilerini gönderebilmektedir. Performans ve kalibrasyon için yapılan eğilme testlerinden elde edilen sonuçların, literatürdeki benzerleri ile uyumlu olduğu gözlemlenmiştir.
\end{abstract}

Anahtar kelimeler: Ankastre tip eğilmeli yorulma, Çok numuneli test makinesi, Kompozit levha, Sehim-kontrollü yorulma

\begin{abstract}
In this study, a unique fatigue testing machine, which characterizes the flexural fatigue behavior of fiber-reinforced composite plates, wooden plates, plastic-based plates and light metal plates, has been developed. Fixed-end type flexural fatigue test machine, which can be controlled by developed special computer software, uses displacement control method for fatigue tests. Fatigue tests are long-running mechanical tests. The developed fatigue test machine can save time and energy under favor of the ability to test 10 samples simultaneously. Fatigue tests can be performed under different displacement rates $(R)$ and $0,1-1 H z$ frequency with simple data entries via the software interface. All parameters such as test time, test frequency, bending force, loss of stiffness, load repetition for each sample can be monitored and controlled both in software interface and on internet. If any of the specimens are damaged, a warning message is sent to the investigator's e-mail along with the relevant test data. It has been observed that the results, which were obtained from the bending tests performing for performance and calibration, are consistent with those in the literature.
\end{abstract}

Keywords: Fixed-end type flexural fatigue, Multi-sample testing machine, Composite plates, Displacement-controlled fatigue

\footnotetext{
*a H Ersen BALCIOĞLU; ersen.balcioglu@usak.edu.tr; Tel: (0276) 22121 36; orcid.org/0000-0002-8579-5142

${ }^{\mathrm{b}}$ orcid.org/0000-0001-6009-9573 $\quad{ }^{\mathrm{c}}$ orcid.org/0000-0003-0573-4962 $\quad{ }^{\mathrm{d}}$ orcid.org/0000-0001-8107-5036
} 


\section{Giriş}

Makine tasarım ve imalatı sırasında tasarımcılar için önemli aşamalardan birisi de malzeme seçimi ve boyutlandırma aşamasıdır. $\mathrm{Bu}$ aşama, makinenin ergonomik yapısını ve kullanılan malzeme miktarı, işçilik vb. gibi üretim maliyetlerini doğrudan etkilemektedir. Tasarımciların boyutlandirma sirasinda malzemenin statik mukavemet değerlerine bağlı kalması her zaman doğru bir yaklaşım değildir. Tekrarlı yüklemeler altında çalışan malzemeler, statik dayanımlarının altındaki gerilme değerlerinde hasara uğrayabilmektedirler. Literatürde bu şekilde hasara uğrama olayı "yorulma" veya "yorulma hasarı" olarak adlandırılmaktadır. Dinamik yükler altında çalışan makine elemanlarının tasarımı ve boyutlandırılması için yorulma davranışlarının ve dayanımlarının doğru olarak bilinmesi gerekmektedir. Statik deneylerin aksine, yorulma deneyleri yükleme tipine farklılık gösteren ve uzun süren deneylerdir. Bu bağlamda uzun süre çalışabilecek konstrüksiyona sahip, farklı parametreler altında yorulma deneyi yapabilen ve bu parametrelere ait her bir veriyi kayıssiz alabilen bir test cihazı tasarlamak önemlidir.

Gelişen üretim teknolojileri ve azalan doğal kaynaklar üreticileri geleneksel imalat malzemelerine alternatif olabilecek yeni arayışlara sevk etmiştir. Günümüzde üretici ve son kullanıcıların yapı malzemelerinden beklentileri düşük ağırlık ve buna karşın yüksek mukavemet özelliğidir. Özellikle havacılık, otomotiv ve savunma sanayi gibi sektörlerde ağırlık kazanan bu istek kompozit yapı malzemelerinin doğuşunu tetiklemiştir. Kompozit malzemeler, iki ya da daha fazla malzemenin kendi özelliklerinden daha üstün özellikte bir yapı meydana getirmek için makro düzeyde birleşmesiyle meydana gelen yapilardır. Kompozit gibi heterojen malzemeler anizotropik yapıda olduğu için geleneksel yorulma cihazları ve yöntemleri ile yorulma davranış parametrelerini karakterize etmek zordur (Mokhtarnia vd., 2016; Sakin ve Ay, 2008). Önemli parametrelerin ayarı ve kontrolü bu cihazlar ile kolay değildir. Bu durum yüksek hata oranlı sonuçlar elde edilmesine sebep olur. Buna ek olarak, servo-hidrolik yorulma test makinelerinin bakım ve servis maliyetleri oldukça yüksektir. Ayrıca, bu test makinelerinde test sürecinde sürekli operatörün dikkati gerekir. Uygulamada karşılaşılan bu ve benzer eksikliklerden dolayı, kompozitin önemli test parametrelerinin tanımlanması ve lineer-olmayan hasar mekanizmasının etkisi altındaki yorulma hasar sürecinin değerlendirilmesi zordur. Bu tür cihazların bir diğer kısıtlılığı, farklı frekans ve gerilme oranları gibi bütün önemli test parametrelerini karş1layacak kapasiteye sahip olmamalarıdır (Ben Zineb vd., 2003; Hoefnagels vd., 2008; Kolluri vd., 2009; Mokhtarnia vd., 2016). Ayrıca, bu cihazların birçoğunda aynı anda ancak tek bir numunenin test edilebilmesi, hem test süresini hem de test maliyetini çok fazla arttırmaktadır. Bazı çalışmalarda ise test süresini azaltmak için yüksek frekans üreten vibrasyon cihazları geliştirilmiştir (Foong vd. 2006; George, 2004; Mokhtarnia vd., 2016; Stanzl-Tschegg, 2014; Xue vd. 2008; Yun vd., 2012). Yorulma testlerinde malzemenin yorulma ömrünün belirleyen en önemli iki parametre genlik ve frekanstır. Yüksek frekans altında yapılan yorulma testi sonuçları ile düşük frekansta çalışacak bir malzemenin seçimini yapmak ve o malzemenin yorulma ömrünü yorumlamak doğru değildir. Örneğin, yüksek frekans yorulma cihazlar1 ile rüzgâr türbininde ya da gemi pervanelerinde yap1 malzemesi olarak kullanılacak ve düşük frekanslarda çalışacak kompozit malzemeyi test etmek, sonuçlara göre fiber malzemesi seçimi ya da boyutlandırma yapmak uygun değildir (Lai vd., 2011). Yorulma cihazın test frekansı ile gerçek yükleme şartları altında çalışan malzemenin rezonans frekansı da aynı olmalıdır (Mokhtarnia vd., 2016). Ayrıca yüksek frekans test cihazları, yalnızca belirli bir boyut ve şekle sahip numuneleri bağlayabilme gibi bazı dezavantajları vardır. Dolayısıyla yüksek frekanstaki titreşim bazlı cihazlar ile yapılan çalışmalar (Di Benedetto vd., 2004; George, 2004; Ghielmetti vd., 2011; Stanzl-Tschegg, 2014; Xue vd., 2008; Yun vd., 2012) yukarıda açıklanan sinırlamalardan dolayı gerçekte düşük frekans altında çalışan fiber takviyeli polimer kompozitlerin yorulma araştırması için uygun değildir. Bunun yanında, kompozitler için standart test frekansı aralığı 1-10 Hz gibi düşük frekanstır. Çünkü yüksek frekanslarda, kompozitin izotermal davranışları ve histeretik 1sıtmadan dolayı test sırasında sıcaklık artışları meydana gelir (Ay vd., 2008; Mokhtarnia vd., 2016; Sakin vd., 2008).

$\mathrm{Bu}$ çalışmada, önceki yorulma test makinelerindeki sınırlamalar ve dezavantajların dayattığ1 zorluklar, toplam test süresi, mekanik verimlilik, düşük üretim maliyeti gibi özellikler göz önüne alındığında fiber takviyeli kompozit plakaların yorulma davranışlarının incelenmesi için çok numuneli yeni bir yorulma test makinesi geliştirmek hedeflenmiştir. Yorulma gibi dinamik testlerde, statik testlerde olduğu gibi belirgin bir hasar şekli (kırılma, ayrılma, büyük şekil 
değişimleri vb.) ortaya çıkmayabilir. Bu duruma sıklıkla polimer matrisli kompozit malzemelerde karşılaşılmaktadır. Böyle bir durumda polimer matrisli kompozit malzemelerin yorulma mukavemeti-yorulma ömrünü gösteren S-N eğrisini (Wöhler eğrisi) elde etmek için fazla sayıda deney yapma zaruriyetini ortaya çıkarmaktadır. Ayrıca elde edilen birbirinden farklı sonuçları doğru anlayabilmemiz için sonuçların istatistiki olarak yorumlanması gerekmektedir. İstatistiksel analizde kullanılması gereken veri adedi de deney sayısını arttırmaktadır. Çalışma kapsamında tasarım ve imalatı gerçekleştirilen sehim kontrollü eğilmeli yorulma cihazı aynı anda 10 adet numuneyi test edebilecek kapasiteye sahiptir. Yükleme frekansı ve gerilme oranı gibi parametrelerin ayarlanabileceği şekilde bir kontrol ve yazılım sistemi ile donatılmıştır. Buna ek olarak, yük çevrimi ve gerilme (rijitlik kaybı) değişimlerinin izlenmesi ve ölçülmesi için bir ölçüm sistemi geliştirilip, kalibre edilmiştir. Sonuçta, yorulma test makinenin performans ve kalibrasyonu fiber takviyeli kompozit levhalar üzerinde yapılan yorulma testleriyle değerlendirilmiştir.

Özellikler hafif levha tipi malzemeler için çok az sayıda "çok numuneli" yorulma tasarımı yapılmış test makinesi vardır (Ay vd., 2008; Sakin, 2016; Sakin vd., 2008; Waring vd., 1980; Wu vd., 2001; Yun vd., 2012). Bu nedenle, bu çalışma literatürde yapılan diğer çalışmalardan farklı olarak uzaktan kontrol edilebilir kullanıcı dostu ara yüze sahip olması, yüksek frekanslarda dahi her bir numune için anlık yorulma verilerinin kayıssız alınabilmesi gibi özelliklere sahip olmasından dolay1 özgündür. Yorulma test cihazı servo motorundan aldığı tahrikle deplasman kontrollü olarak yorulma testini gerçekleştirmektedir. Yazılım ara yüzü üzerinden yapılacak basit veri girişleri ile farklı test frekansları ve farklı sehim oranları (R) altında testler yapılabilir. Cam, karbon, aramid gibi fiber takviyeli kompozit levhaların yanı sıra, diğer genel olarak test edilebilecek malzemeler; ahşap levhalar, plastik esasli levhalar, fiber takviyeli kompozit levhalar ile alüminyum gibi hafif metalik levhalardır.

\section{Materyal ve Metot}

\subsection{Tasarım Esaslart}

Yorulma test makinelerinin hemen hemen tamamında aynı anda "tek numune" test edilir. Hâlbuki malzemenin yorulma dayanım sınırını karakterize eden S-N eğrilerini elde edebilmek için, her bir sehim veya gerilme değerine karşıllık en az 5 adet numune test etmek gerekir. Genel olarak; S-N eğrisini doğru olarak oluşturabilmek için malzemelerin maksimum dayanımından yaklaşık $\% 20$ oranında sürekli azaltılarak 7-8 farklı nokta için testler tekrarlanır. Bu durumda, tek bir malzeme parametresi için elde edilecek S$\mathrm{N}$ eğrisi için ortalama 35-40 adet numunenin yorulma testine tabi tutulması anlamina gelir. Klasik yorulma test makinelerine örnek olarak; 2 farklı malzeme parametresi için, $10 \mathrm{~Hz}$ test frekansı altında, her bir gerilme noktası için 5 adet numune, her bir parametre için 40'ar adet numune olmak üzere toplam 80 adet numune kullanmak gerekir. $\mathrm{Bu}$ durumda, 10 milyon yük tekrar sayısına kadar devam etmesini planladığımız "yüksek çevrimli yorulma" testi için numune bağlama ve diğer yan süreler hariç toplam test süresi yaklaşık 146 gündür. $\mathrm{Bu}$ çalışmadaki on numuneli test makinesinde ise toplam test süresi on kat azalmaktadır. Özellikle kompozitlerin yorulma testlerinde $10 \mathrm{~Hz}$ 'lik frekansin üzerine çıkılmaması önerildiğinden ve bu testler çok uzun sürmesi, pahalı ve zahmetli olduğundan toplam test süresi büyük önem arz etmektedir (Di Franco, Marannano, Pasta, \& Mariotti, 2011).

Klasik eğilmeli yorulma test makinelerinin hemen hemen tamamında sehim değeri, krank-biyel mekanizması ile elde edilir. Maksimum ve minimum sehim değeri genelde mekanik konstrüksiyon üzerinden el yardımıyla ayarlanmaktadır. Dinamik çalışma anında bu mekanizmalar ile "sabit bir sehim değeri" elde etmek hem zordur hem de hassasiyet konusu tartışmalıdır. Krank-biyel mekanizması kullanılan eğilmeli yorulma testlerinde, farklı sehim veya gerilme oranı (R) altında test yapmak zordur. Çünkü test frekansı arttıkça her farklı gerilme oranı (R) elde etmek için, krank yarıçapı, biyel kolu uzunluğu veya numune bağlama mesafesinin değiştirilmesi gerekir. Ayrıca bu tip test cihazlarında yapılan yorulma testlerinde yüksek frekanstan dolayı merkezkaç kuvvetinin de etkisi devreye girmektedir. Geliştirdiğimiz test makinesinde "sehim değeri"; yazılım ile kontrol edilen servo-motorun sağa/sola döndürülmesi vasitasiyla ileri/geri hareket eden lineer vidalı hareket tablası sayesinde $5 \mu \mathrm{m}$ hassasiyetle sağlanmaktadır. Ayrıca klasik test makinelerine kıyasla, test süresince bu gerilme oran1 değişmeden aynı hassasiyetle tekrarlanabilir.

Klasik yorulma test makinelerinde, test için "başlangıç sıfır pozisyonunu" tanımlamak ve ayarlamak, bir diğer önemli zorluktur. Ankastre tip yorulma cihazlarında sifir pozisyonu tam belirlenemezse, eksen kaçıklığından dolayı 
oluşacak moment numunede ön gerilmeye sebep olur. $\mathrm{Bu}$ durum malzemenin gerçek $\mathrm{S}-\mathrm{N}$ eğrisinin belirlenmesinde olumsuz yönde etki etmektedir. Çalışma kapsamında geliştirilen yorulma test makinesinde hafizaya kayıtlı olan "başlangıç sıfır pozisyonu" tanımlama işlemi yazılım ara yüzündeki tek bir buton ile sağlanmaktadır. Yani test tamamlandığında cihaz dur butonu ile başlangıç sıfir pozisyonuna gider ve devamındaki teste aynı konumdan başlar. Klasik yorulma test makinelerinde ani bir problemden dolayı makine durdurulduğunda, tekrar çalıştırma anına kadar geçmişte elde edilen eğme kuvveti ve rijitlik kaybı, yük tekrar sayısı gibi çok kıymetli verilerin ne olduğu konusu tartışmalıdır. Bu çalışmadaki yorulma test makinesi için geliştirdiğimiz yazılım ara yüzü üzerindeki "teste devam" butonu sayesinde önceki verilerin üzerine ilave edilerek "veri kaybı olmaksızın" teste devam edilebilir. Yukarıda bahsedilen ve tekniğin en çok bilinen klasik eğilmeli yorulma test makinelerine örnek olarak literatürdeki çalışmalar verilebilir (AboElkhier vd., 2014; Azzam ve Li, 2014; Babu ve Srinivas, 2014; Bura ve Dvr, 2014; Di Franco vd., 2011; Filatov, 1989; Koricho vd. 2014; Mini vd., 2012). Çok numuneli eğilmeli yorulma test makineleri için literatürdeki, çekme-çekme (Ay vd., 2008; Sakin, 2016; Sakin vd., 2008; Yamamoto vd., 2013; Yun vd., 2012), basmabasma (Pach vd., 2012; Shokrieh vd., 2014) ve kayma tipi (Degallaix vd., 2002; Philippidis ve Vassilopoulos, 2002) yorulma test makineleri örnek verilebilir.

\subsection{Kontrol Yazılımı ve Ara Yüzü}

Bilgisayar kontrollü ankastre-tip eğilmeli yorulma test makinesi geliştirilen yazılım sayesinde tamamen bilgisayar kontrollü olarak çalışmaktadır. Çalışma kapsamında geliştirilen yazılım ara yüzü Main Menu, Graphichs ve Load signal (1) olmak üzere 3 ana sekmede derlemiştir (Şekil 1).

Main Menü sekmesinde test parametrelerine ait veriler gösterilmektedir. $\mathrm{Bu}$ sekme üzerinde yorulma testinden elde edilen verilen saklanma sıklığı, yorulma hasar kriteri gibi test parametrelerinin giriş yapılmaktadır. Ayrıca test süresi, çevrim sayıs1, lineer vidalı hareket tablasina ileri/geri hareket miktarı, her bir numune üzerindeki yorulma yükü ve hasara uğrayan test numunelerinin bilgisi takip edilebilmektedir. Bununla birlikte, yazılım 1,5 kW'lık Delta markla servo motorun yazılımı ile senkronize çalışarak, motorun yorulma testi sirasindaki frekans parametrelerini kontrol edebilmektedir.

Graphics sekmesinde test frekansına ait bilgiler grafiksel olarak ifade edilmiştir (Şekil 5). Kontrol edilebilir servo motoru ile yorulma testi surasinda farklı frekans eğrileri (Üçgen kesitli, kare kesitli, sinüzoidal vb.) elde etmek mümkündür. Load signal sekmesinde ise her bir yük hücresinden alınan gram cinsindeki yük değerleri her bir test numunesi için ayrı ayrı okunabilmektedir.

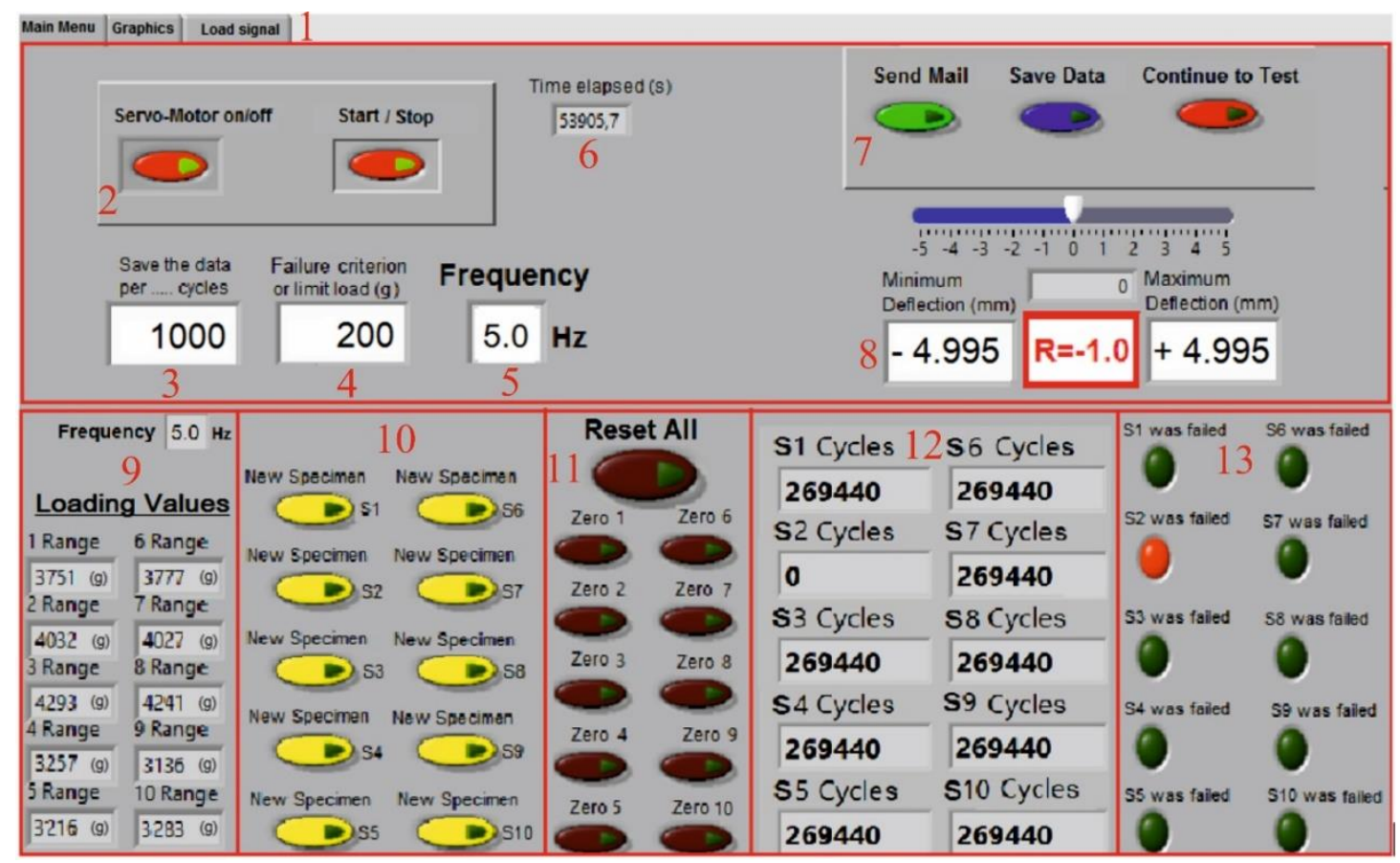

Şekil 1. Yorulması test makinesi için yazılım-ara yüzü 


\subsection{Yorulma Test Makinesi}

10 numuneli ankastre-tip eğilmeli yorulma test makinesi Şekil 2.'de gösterilmiştir. Çalışma prensibinin daha iyi anlaşılması için Şekil 3. üzerindeki parçalar numaralandırılmış ve numaraların tanımları verilmiştir. Lineer vidalı hareket tablasının (17) ileri/geri hareketi esnasında yük hücreleri (19) üzerindeki minimum veya maksimum kuvvet değerleri "gram" olarak yazılım ara yüzünden (3) görülebilir. Aynı zamanda, test anındaki "sehim değeri", (22) nolu sehim kontrol sensörü yardımıyla sürekli olarak yazılım ara yüzünden gösterilmektedir. Böylece, sensör tutucuya (23) monteli olan manyetik okuyucu-lineer enkoder (22) sayesinde sehim değerini hassas izleme ve geri besleme sağlanabilmektedir.

Uzun süren testlerde kullanıcı, yorulma test makinesini çalıştırıpuzaktan makineyi takip edebilir. Bu amaçla, bir IP kamera (9) ve verilen statik IP ile internet bağlantısı ile farklı bir konumdan yorulma test makinesinikontrol ve kumanda edebilir. Test esnasında bütün numuneleri iyi görebilmek için IP kameranın istenilen açıda ayarlanabilir. Acil stop düğmesine (5) basıldığında yorulma makinesi anında durmaktadır. Benzer şekilde, yanlış bir ayar ile lineer vidalı hareket tablası hareket sınırları dışına çıkmaya çalışırsa limit emniyet sensörleri (30) devreye girerek servo-motorun (18) hareketini durdurur. Ana pano içinde elektrik/elektronik sistem devre elemanları, PC kasası (2) içinde verilerin kayıpsız ve hızlı bir şekilde kaydedilmesini sağlayan katı hal diski (SSD) ve yük hücrelerinden alınan elektrik sinyallerinin sayısal verilere çeviren DAQ kart mevcuttur. Yorulma test makinesi üzerindeki titreşimleri azaltmak için ise, test makinesi şasesi (12) ile alt bağlama U-profili (13) arasında dört adet lastik takoz (14) kullanılmıştır.

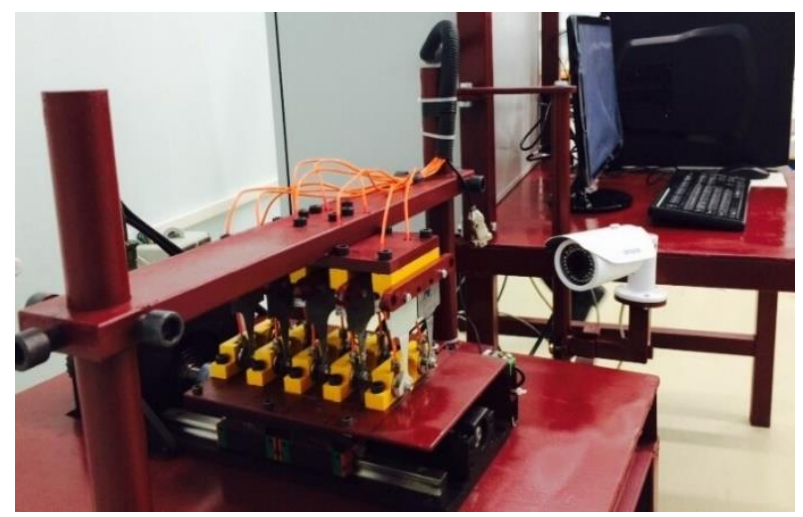

Şekil 2. Bilgisayar kontrollü çok numuneli ankastre tip eğilmeli yorulma test cihazı
Viskoelastik malzemelerin yorulma incelenmesi iki modda yapılır; özellikle yorulma mekanizmasının değerlendirilmesi prosedüründe, test metoduna göre ya sehim-kontrollü veya gerilme-kontrollü olarak iki farklı modda testler yapilır (Mokhtarnia vd., 2016; Roudet, 2002). Bu çalışmadaki yorulma test cihazının ana özelliği, sabit sehim-kontrollü test yapabilme kabiliyetidir.

\subsection{Test Sisteminin Tasarımında Dikkate Alınan Parametreler}

$\mathrm{Bu}$ çalışmanın öncesinde, bilgisayar kontrollü ve çok numuneli eğilmeli yorulma test makinesini tasarlamak için bazı temel ve önemli ihtiyaçlara karar verilmiş ve aşağıdaki gereksinimler ve teknik problemlerin çözümü karşılanması amaçlanmıştır:

1. Sehim (deplasman) kontrollü yorulma testi uygulama becerisi;

2. Aynı anda 5 veya 10 adet numuneyi yorulma testine tabi tutma özelliği; Böylece klasik test makinelerine göre10 kata kadar zaman tasarrufunun sağlanması.

3. Servo-motor ve yazilımı sayesinde; klasik test makinelerinden farklı olarak istenen sehim değerleri $5 \mu \mathrm{m}$ hassasiyetinde uygulanabilmesi ve test süresince sabit kalmasi.

4. Herhangi bir pozitif veya negatif $R$ oranında $\left(\mathrm{R}=\varepsilon_{\min } / \varepsilon_{\max }\right)$ test yapılabilme yeteneği; Sehim değerleri, lineer enkoder ve manyetik okuyucu sensör ile hassas olarak gözlenmesi ve geri besleme sağlanabilmesi.

5. ASTM D671 standardına uygun Tip-A ve Tip-B numune ve farklı ölçülerde dikdörtgen boyutlarda düz numune bağlayabilme özelliğinin olması. Bu düz numunelerin boyut sinırları ise iki grup olarak belirlenebilmesi; a) $8.9-25.4 \mathrm{~mm}$ arasinda en, $50.8-190.5 \mathrm{~mm}$ arasinda boya sahip 10 adet numune sağ ve sol bloktaki numune yerlerine, b) maksimum $50.8 \mathrm{~mm}$ en ve maksimum $190.5 \mathrm{~mm}$ boya sahip olan 5 adet numune merkezdeki orta bloğa bağlanabilmesi.

6. Yük kapasitesi her bir yük hücresi için maksimum $500 \mathrm{~N}$ olmak üzere toplam 5000 N'dur.

7. Servo-motor sürücüsünün kontrol paneli üzerindeki parametrelerin ayarlanması ile farklı yükleme dalga şekilleri (kare, üçgen, yamuk vb. formlar) oluşturma yeteneğinin olmas1; 
8. Teste başlangıç "sıfır pozisyon" ayarının hassas olarak elde edilebilme imkânının olmasi;

9. Farklı yükleme frekansları $(0.1-10 \mathrm{~Hz})$ oluşturma ve ayarlama yeteneğine sahip olmas1;

10. Yüksek çözünürlüklü IP kamera ile internet veya yerel ağ üzerinden çevrimiçi izleme ve uzaktan kontrol edilerek başında operatör olmadan 7 gün 24 saat çalışma özelliğine sahip olmas1;

11. Her bir test numunesinin hareketli ucuna monteli yük hücreleri sayesinde, test süresince numunelerin yatay yönde taşıdığ eğilme kuvvetini ölçme özelliğine sahip olması ve ayrıca, bu yük hücreleri sayesinde testin her anında her bir numunenin "rijitlik kaybı" yazılım üzerinden izlenebilmesi.

12. Bütün parametre ve verilerin (test frekans1, eğme kuvveti, zaman, yük tekrar sayısı vs.) bilgisayarın diskine (SSD) anlık veya girilen "yük tekrar sayısı" aralıklarında kaydetme özelliğinin olmas1;

13. Teste ara verildiğinde geçmişte elde edilen verilerin "teste devam" tuşu ile yeni verilere ilave edilme özelliği sayesinde veri kaybı olmaksızın teste devam edilebilmesi.

14. Test esnasinda herhangi bir numune kırıldığında veya girilen rijitlik kaybına uğrayarak hasar gördüğünde, sistem otomatik olarak tanımlanan araştırmacıya bilgilendirme e-postas1 (numune no, kırılma yükü, hasar çevrim sayısı, zaman, vb.) gönderebilmesi.

15. Düşük üretim, bakım ve çalıştırma maliyetine sahip olması; düşük bakım ve çalışma maliyeti ve operasyonel sadeliği ile bir yorulma test makinesinin tasarımı ve imalatı arzulanan bir durumdur.

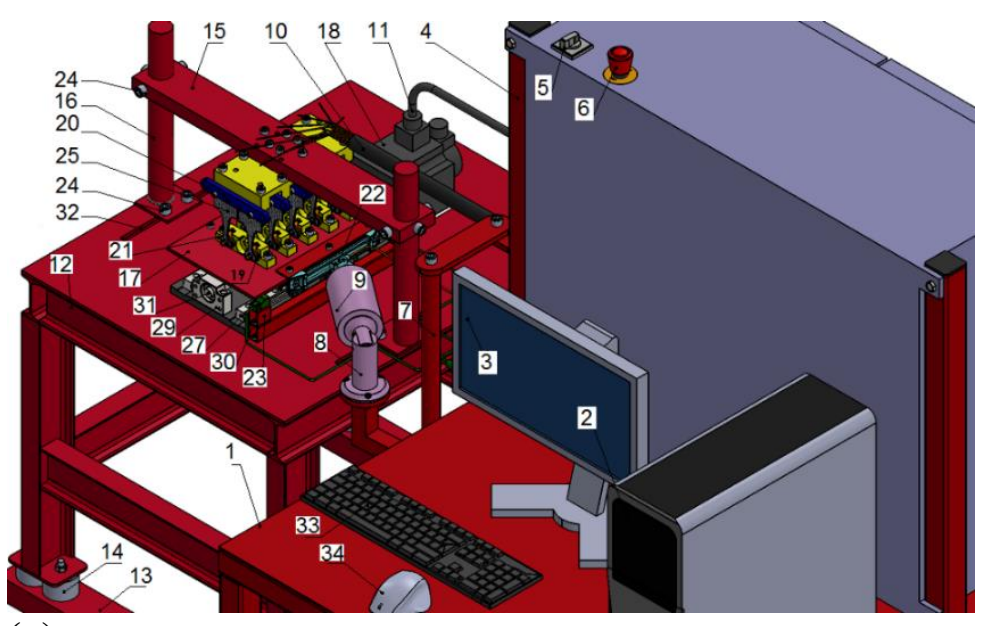

(a)

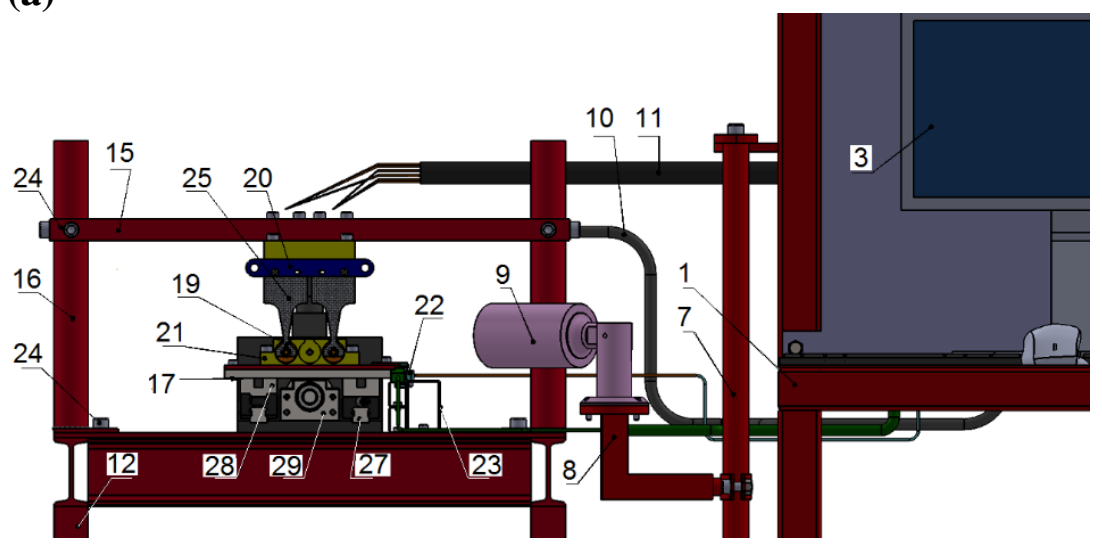

(b)
1. Şase-1

2. $\mathrm{PC}$

3. Yazılım ara yüzü

4. Ana kontrol paneli

5. Sistem başla/durdur butonu

6. Acil stop-switch

7. Döner kamera tutucu

8. Kamera ayarlama mekanizmas1

9. IP kamera

10. Yük hücresi kabloları

11. Güç kablosu

12. Şase- 2

13. Alt sabitleme U-profil

14. Kauçuk amortisörler

15. Yükseklik ayarlama bloğu

16. Tutucu kollar

17. Lineer kayma tablas 1

18. Servo-motor

19. Yük hücresi

20. Tutucu-1 (numune sabitleme yeri)

21. Tutucu-2 (numune hareket bölgesi)

22. Manyetik okuyucular ve lineer enkoder

23. Sensor tutucu

24. Mesafe ayarlama vidaları

25 . Test numuneleri

26. Kaplinler

27. Lineer kızaklar

28. Lineer raylar

29. Rulmanlar

30. Limit-emniyet sensörleri

31. Vidalı mil $($ adım $=20 \mathrm{~mm})$

32. Sürgülü taban plakası

33. Klavye

34. Mouse

Şekil 3. Yorulma test cihazı (a) izometrik (b) ön görünüş. 


\subsection{Servo-Motor ve Lineer Vidalı Hareket Tablast}

Yorulma makinesinde, eğilme yükü servo-motor tarafindan tahrik edilen lineer vidalı hareket tablasının ileri-geri hareketi ile verilir. Eğilme yükü ise, her bir numunenin hareketli tarafindaki numune tutucuya sabitlenen yük hücreleri tarafindan ölçülmektedir. $\mathrm{Bu}$ mekanizma ile monotonik, tekrarlı, sehim-kontrollü testi mümkün olabilmektedir.

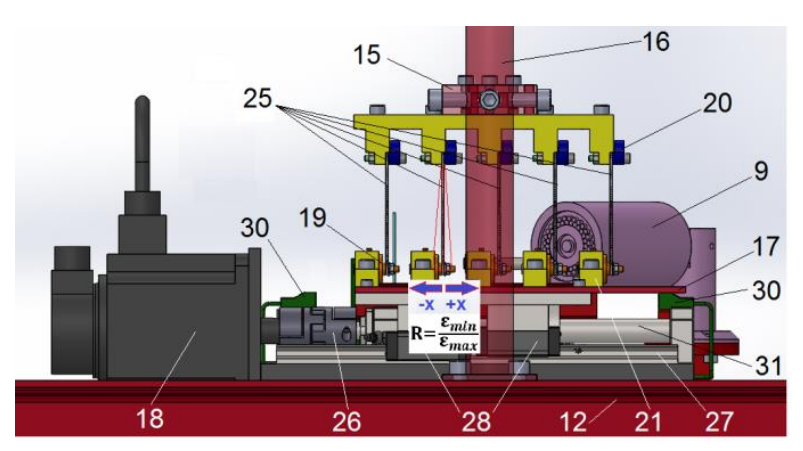

Şekil 4. Yorulma test cihazı yan görünüş

Lineer vidalı hareket tablası sisteminin en önemli parçaları, servo-motor (18) ve $20 \mathrm{~mm}$ vida adımına sahip ana milidir (17) (Şekil 4.). Servo motor ve servo sürücüye ait özellikler Tablo 1.'de verilmiştir. Ana mil için gerekli olan güç, direk olarak servo-motor tarafindan sağlanır. Bu sistem Şekil-4'de görülmektedir. Servo-motorun mili kaplin (30) ile yük miline bağlanmıştır. Farklı yükleme frekansları yazılım ara yüzünden girilecek sehim değerleri ile üçgen dalga form elde edilmektedir. Şekil-5'de $5 \mathrm{~Hz}$ frekans altında tam-değişken $(R=-1)$ yüklemede tipik bir üçgen dalga formu verilmiştir. Diğer dalga formları ise servo-motorun kendi yazılımı üzerinden kontrol ederek elde edilebilir.

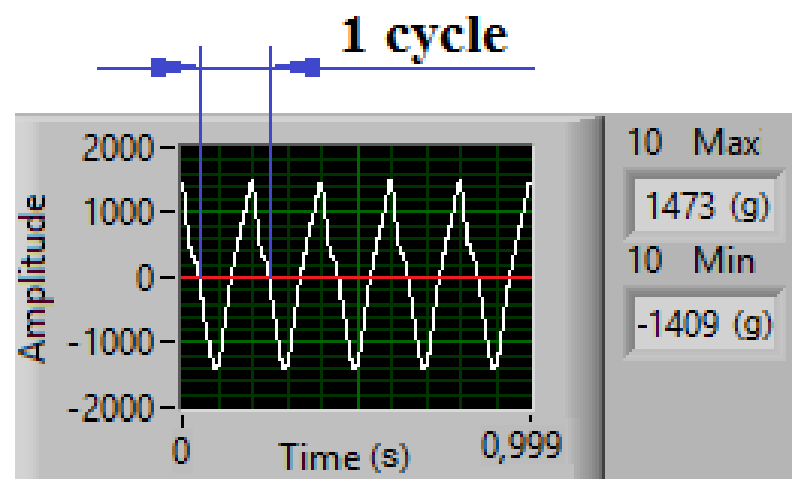

Şekil 5. $5 \mathrm{~Hz}$ frekans altında tam-değişken $(\mathrm{R}=-1)$ yüklemede tipik bir üçgen dalga formu
Tablo 1. Servo motor ve servo sürücünün özellikleri

\begin{tabular}{|l|l|}
\hline Firma & DELTA ELECTRONICS \\
\hline Motor model & ECMA - E11315RS \\
\hline Nominal güç & $1.5 \mathrm{~kW}$ \\
\hline Nominal hız & $2000 \mathrm{rpm}$ \\
\hline Nominal tork & $7.16 \mathrm{~N} . \mathrm{m}$ \\
\hline Nominal akım & $8 \mathrm{~A}$ \\
\hline Sürücü modeli & ASD-A2-1521 M \\
\hline Mode & Pozisyon ve hız kontrollü \\
\hline
\end{tabular}

\subsection{Uzaktan Test, Veri Takip ve Uyart Sistemi}

Uzaktan test, veri takip ve uyarı sistemi ise Şekil 6 'daki akış diyagramı ile daha iyi açıklanabilir.

\subsection{Kontrol Birimi ve Bilgisayarlı Ölçüm}

Ana pano içi ve bilgisayarlı ölçme bölümü Şekil7'de gösterilmiştir. Ölçüm birimi, yük hücreleri, amplifikatör, DAQ konnektör bloğu ve PC'den oluşur. Yük hücresi çıkışındaki mili volt mertebesineki sinyali, amplifikatör yükseltilir ve DAQ kartla bütünleşmiş bir $\mathrm{A} / \mathrm{D}$ dönüştürücüsü tarafindan bilgisayara aktarılır. $\mathrm{Bu}$ amaçla LabView ile bir alt program yazılarak ve bu program çıkış gerilimi gram olarak yük değerlerine çevrilerek kayıt etmede kullanılmıştır.

Otomasyon endüstrisindeki ağırlık/tork algılayıcı (sensör) olarak genelde yük hücresi (load cell) kullanılır ve ağırlığın oluşturduğu gerilme ya da burulma elektronik yöntemle ölçülür. Geliştirilen yorulma test cihazının yük hücreleri, daha önceden ağırlıkları belirlenmiş yüklerle kalibre edilmiştir. Kalibrasyon sirasında her bir farklı yük değerine karşılık gelen çıkış gerilimi okunmuştur ve yük değerine karşılık gelen çıkış gerilimi lineer fonksiyon ile her bir yük hücresi için ayrı ayrı formüle edilmiştir. Şekil-8'de görüldügü gibi, programda yük ve çıkış gerilimlerindeki değişiklikler bir grafik üzerinde çizdirilerek kalibrasyon katsayıları tespit edildi. Grafikten de görüldüğü gibi, yük ve çıkış geriliminin değişiminin ilişkisi lineerdir. Aynı zamanda burada, hasar mekanizmasını değerlendirmesi için yük - yük çevrimleri yazılım ara yüzünden anlık olarak da izlenebilir. 


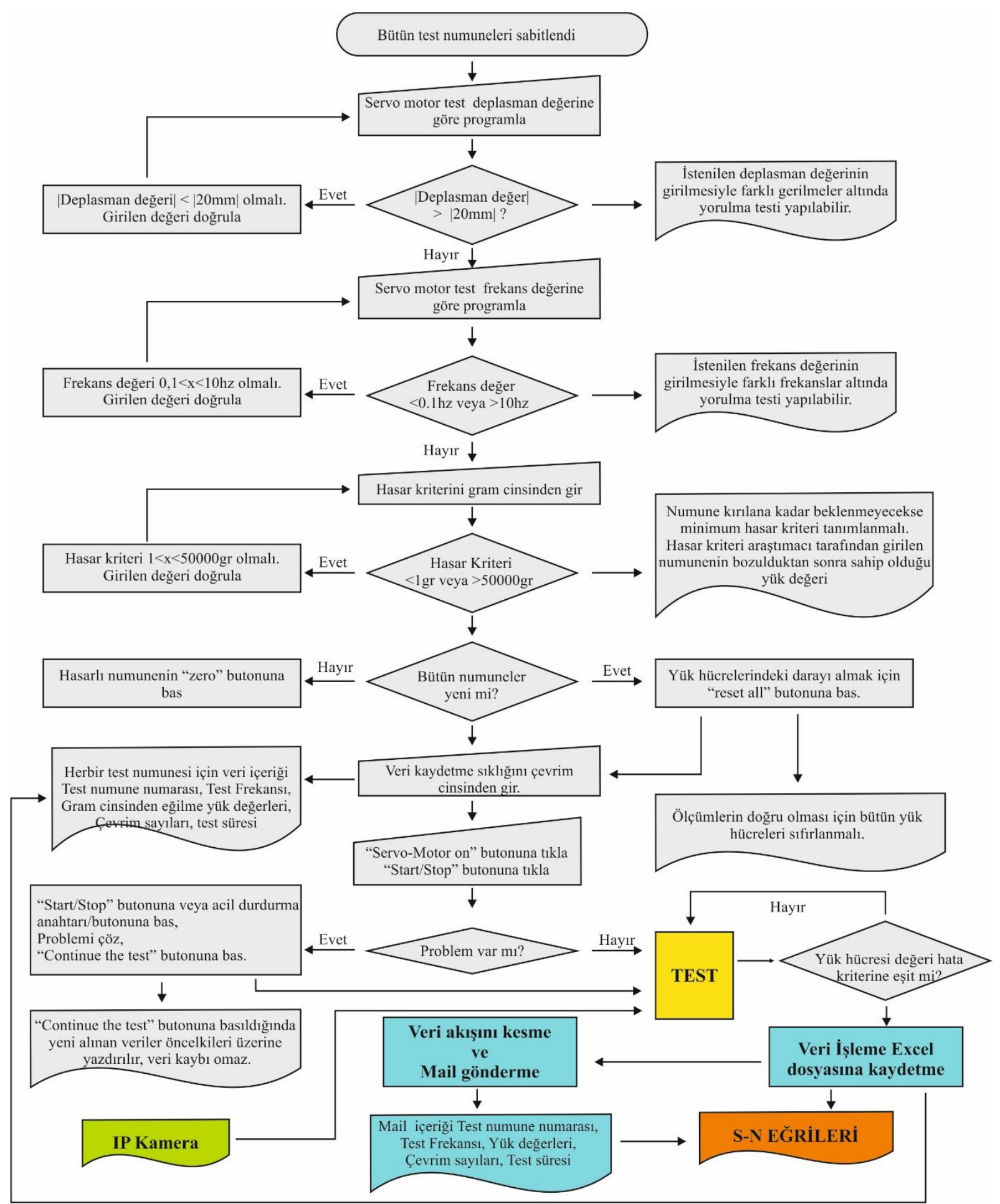

(a) 


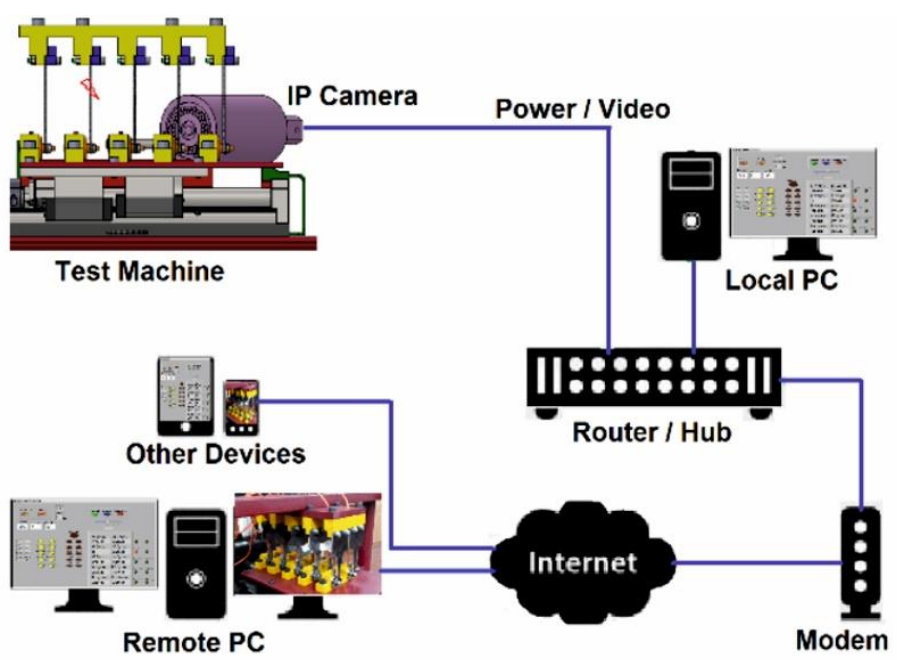

(b)

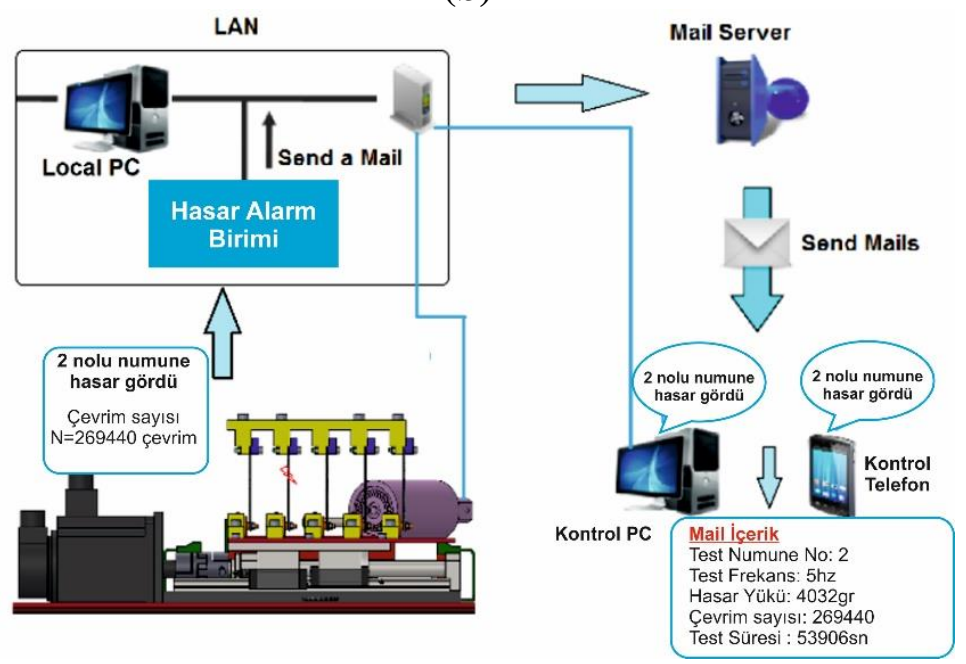

(c)

Şekil 6. Yorulma test makinesinin (a) çalışma sistemi, (b) uzaktan test, (c) veri takip ve uyarı sistemi için akış diyagramı

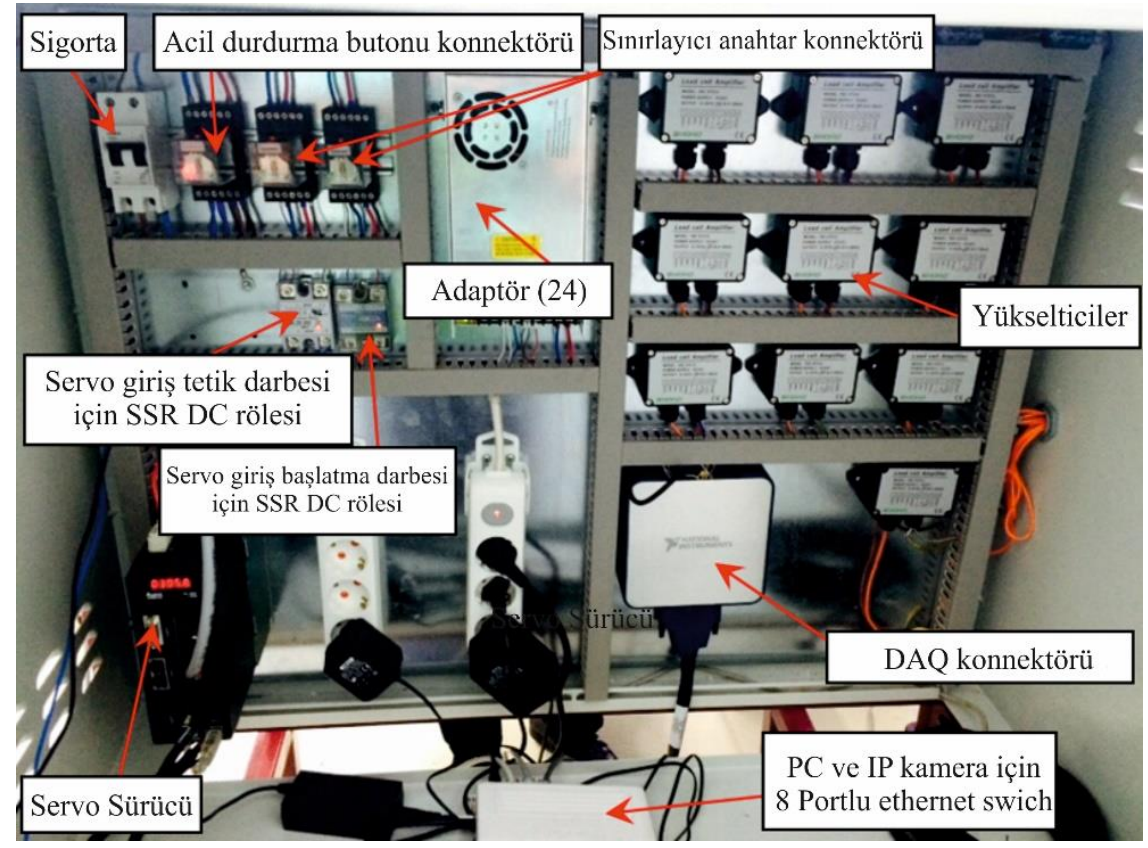

Şekil 7. Ana pano içi ve bilgisayarlı ölçme bölümü 


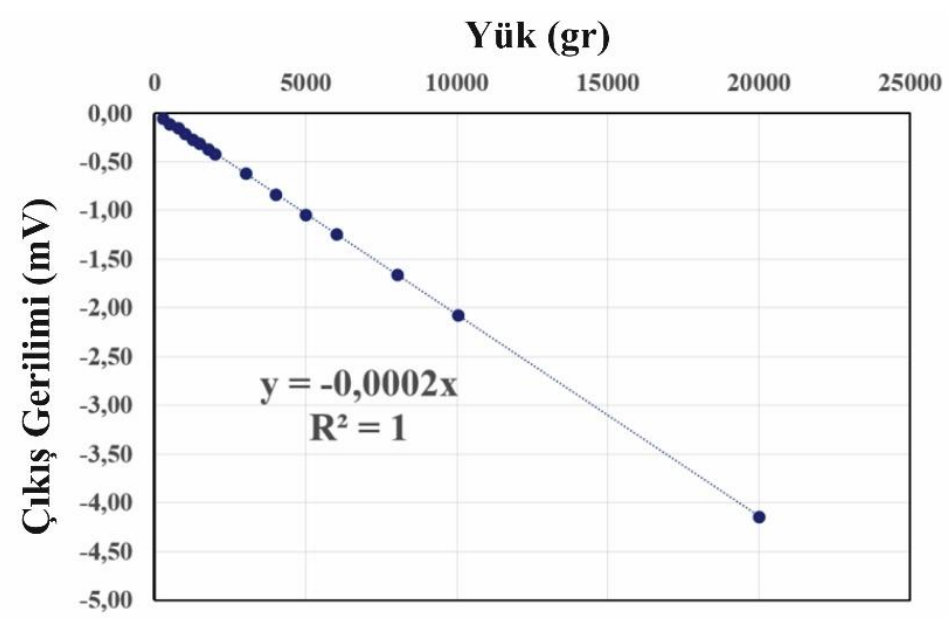

Şekil 8. Yük hücresinin kalibrasyon eğrisi

\section{Performans ve Kalibrasyon İçin Yorulma Testleri}

Tasarım ve imalatı tamamlanan ankastre-tip eğilmeli yorulma test makinesinin kalibrasyon ve performans testleri için kullanılan e-cam/epoksi $\left(\mathrm{C}_{8}\right)$ tabakalı kompozit malzemeler, sekiz tabakalı olarak el yatırma yöntemi ile üretilmiştir. Cam fiber dokuma kumaşta fiberler $\left[0^{\circ} / 90^{\circ}\right]$ fiber yönlenmesine sahip olup düz dokuma yapısında dokumuştur. Kullanılan cam elyaf dokuma kumaşlar $300 \mathrm{gr} / \mathrm{m}^{2}$ ağırlığa sahiptirler. Matris malzemesi olarak DURATEK Firmasında satın alınan DTE1000 reçine ve DTS1100 sertleştiriciye sahip iki bileşenli epoksi reçine kullanılmıştır. Sekiz tabakalı takviye kumaşın ağırlığına eşit ağırlıktaki epoksi matris malzemesi ağırlıkça $\% 75$ 'i reçine ve $\% 25$ 'i sertleştirici olacak şekilde hazırlanmıştır. El yatırma ile laminasyon işlemi sonrasında yarı mamul kompozit plakanın kürleşme işlemi $100^{\circ} \mathrm{C}$ 'de ve 4 saat süresinde isı-zaman-basınç kontrollü hidrolik preste gerçekleştirilmiştir. Ortam basıncı $6 \mathrm{MPa}$ olarak ayarlanmıştır. Üretim sonrasında mamül haline gelen tabakalı kompozit malzeme çarpılma etkisine karşın aynı basınç altında 24 saat süresince soğumaya bırakılmıştır.

Üretilen e-cam/epoksi tabakalı kompozitin yorulma testlerine geçmeden önce malzemenin eğilme mukavemetini belirlemek için statik testler yapıldı (Şekil 9a). Üç nokta eğme testleri, polimer matrisli kompozitlerin eğilme özelliklerini belirlemek için kullanılan ASTM D7264 standardına göre yapılmıştır (ASTM D7264/D7264M - 07, 2015). Eğilme testleri $50 \mathrm{kN}$ kapasiteli U-Test marka üniversal test cihazında gerçekleştirildi. Test cihazının bilgisayar yazılımı yardımıyla test sırasında her bir numuneye ait yük-deplasman grafiği elde edildi (Şekil 9b). Malzemenin statik eğilme dayanımı Denklem 1'den faydalanılarak hesaplanmıştır (ASTM D7264/D7264M - 07, 2015).

$\sigma_{f}=\frac{3 F L}{2 b h^{2}}$

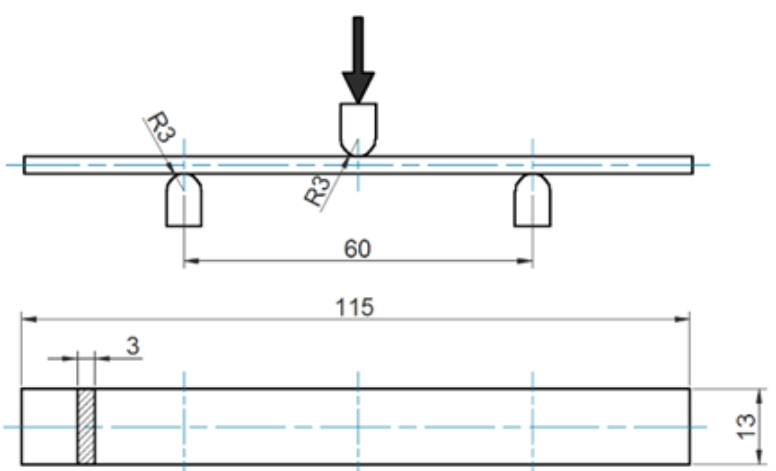

(a)

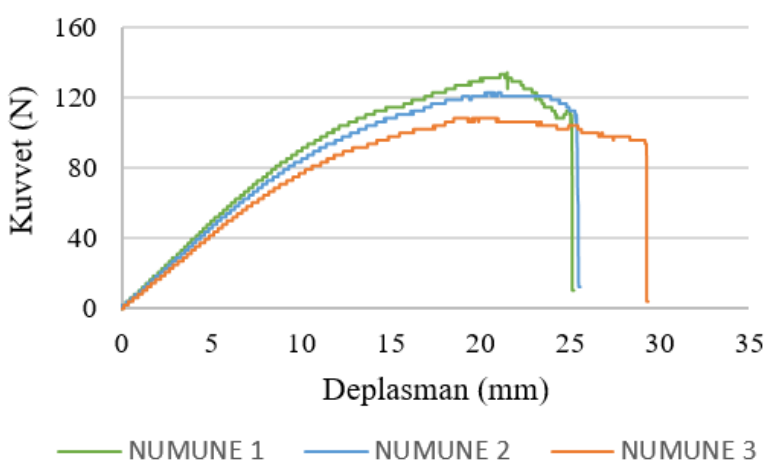

(b)

Şekil 9. Üç nokta eğilme testi (a) eğilme testinin şematik gösterimi, (b) test sonuçları.

Burada " $\sigma_{f}$ " eğilme mukavemetini, "F", eğilme testlerinden elde edilen maksimum kuvvet, "L" 
mesnetler arası mesafe, "b" numunenin genişliği ve "h" numunenin kalınlığını ifade etmektedir. Yorulma testleri malzemenin statik değerinin en az \%20 aşağısındaki gerilme değerlerinden başlanarak daha alt gerilme seviyeleri için tekrarlanır. Burada karşılaşılan sorun statik dayanımı altında kalan gerilme seviyelerini test numunesi bünyesinde meydana getirmektir. Kuvvet kontrollü yorulma test cihazlarında bu sorun numunenin bağlandığı kola ağırlıklar asılır ve eğilme momentinin etkisiyle numune bünyesinde istenilen gerilme oluşturulur (Ay vd., 2008; Sakin ve Ay, 2008; Sakin vd., 2008; Sakin vd., 2008). Çalışma kapsamında imal edilen cihaz deplasman kontrollüdür. $\mathrm{Bu}$ sebeple istenilen gerilme seviyesini meydana getirecek olan şekil değişimi (deplasman) değerinin hesaplanması gerekmektedir. Bu bağlamda malzemenin gerilme ve şekil değişimi arasındaki ilişkiyi ifade eden Hooke yasasından faydalanılmıştır. Denklem (24) kullanılarak istenilen gerilme değerini meydana getirecek olan deplasman değerleri hesaplanmıştır (ASTM D7264/D7264M - 07, 2015).

$\sigma_{f}=\varepsilon \cdot E_{f}$

$\varepsilon=\frac{6 \delta h}{L^{2}}$

$E_{f}=\frac{L^{3} m}{4 b h^{3}}$

$\mathrm{Bu}$ denklemlerde " $\varepsilon$ " eğilme birim şekil değişimini, " $E_{f}$ " eğilme modülünü, " $\delta "$ maksimum eğilme deformasyon miktarını ve "m" üç nokta eğme testinden elde edilen yükdeplasman eğrisindeki lineer bölgenin eğimini göstermektedir. Her kompozit numune grubu için elde edilen maksimum eğilme dayanımı değeri yorulma testlerindeki "bir çevrimlik eğilme dayanımı" olarak kullanılmıştır (Ay vd., 2008; Sakin vd., 2008).

Yorulma testleri için Şekil 10'da görülen ASTM D671-93 test standardına göre hazırlanmış test numunesi kullanılmıştır (ASTM D671-93, 1993). Tasarlanan yorulma cihazı için performans ve kalibrasyon testleri laboratuvar ortaminda (yaklaşı $20^{\circ} \mathrm{C}$ ) ve histeretik 1sıtmayı önlemek için $10 \mathrm{~Hz}$ den daha düşük test frekansı altında gerçekleştirilmiştir. Bu çalışmada, amaca uygun test frekans1 $5.0 \mathrm{~Hz}$ ve testler -1 gerilme oranı (R değeri) altında yürütülmüştür.

Testler sırasında her 1000 çevrimde bir yük hücrelerinden her bir numune için ayrı ayrı değerler alınarak Excel dosyalarına yazdırılmıştır. S-N eğrilerine ait veri noktalarını elde etmek için, testler, kırılma meydana gelmeden önce tamamlanan çevrim (yük-tekrar) sayısına karşılık gelen $\% 80, \% 70, \% 60, \% 50$ ve $\% 40$ farkl1 gerilme seviyesinde yapılmıştır. Yorulma testleri, ilgili grup numuneler \%20'lik rijitlik kaybına ulaşıncaya veya bir numune kırılıncaya kadar sürdürülmüştür (Selmy vd., 2013; Zaman vd., 2014). Eğilmeli yorulma yüklemesi sırasında malzemede kırılmaya ya da yorulma hasarına neden olan yorulma gerilmesi ilgili standartta yer alan ve Denklem 5'te ifade edilen formüle göre hesaplanmıştır (ASTM D671-93, 1993).

$$
\sigma_{\text {yorulma }}=\frac{6 P L}{b h^{2}}
$$

Burada $\mathrm{P}$ yük hücrelerinden okunan değer, L yükün uygulandığı yerden yorulma hasar bölgesine olan mesafe, b numune hasar bölgesinin genişliği ve h numune kalınlığını ifade etmektedir.

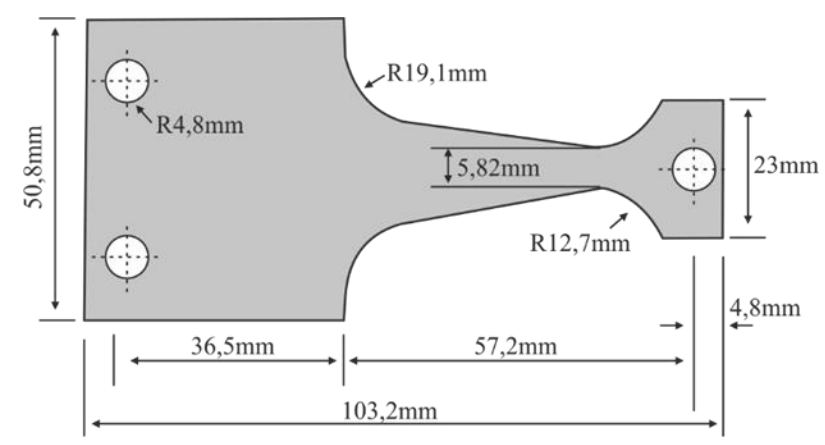

Şekil 10. ASTM D671-93 eğilmeli yorulma test numunesi

Yorulma testi sonuçlarında, düşük gerilme genliklerinde (statik eğilme mukavemetinin $\% 40$ '1) yüklenen test numunelerin kırılmadığ fakat yorulma bölgelerinde delaminasyonların meydana geldiği (Şekil 11), yüksek gerilme genliklerinde (statik eğilme mukavemetinin $\% 80$ 'i) ise yorulma test numunelerinin kırıldığ 1 gözlemlenmiştir (Şekil 12).

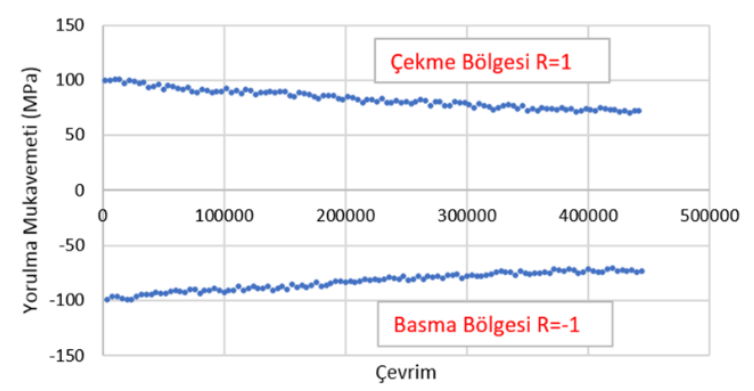

(a) 


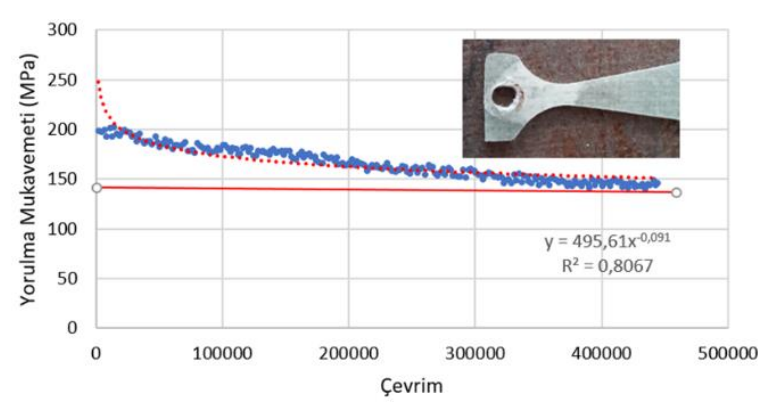

(b)

Şekil 11. Statik mukavemetinin \%40'in de yorulmaya zorlanan test numunesi (a) çeki ve bası bölgesindeki ve (b) toplam yorulma dayanımı değişimi

Şekil 11(a)' da çeki-bası gerilmesi şeklinde eğilme yorulmasına zorlanan test numunesinin çekme $(\mathrm{R}=1)$ bölgesindeki ve basma $(\mathrm{R}=-1)$ bölgesindeki mukavemet kayıları ayrı ayrı verilmiştir. Numunenin çekme ve basma gerilmesi altında benzer şekilde mukavemet kayıpları yaşadığ söylenebilir. Şekil 11(b)'de çekme-bası gerilmeleri toplanarak bir arada verilmiştir. Numunenin eğilme yüklemesi altında kırılmadan hasara uğradığ 1 ve yaklaşı $4 \times 10^{5}$ çevrim sayisindan sonra yorulma mukavemetinde herhangi bir değişim olmadığı; buna karşın numunenin yorulma bölgesinde delaminasyon hasarlarının meydana geldiği görülmüştür. Delaminasyonun başladığı çevrim sayısında test numunesi başlangıçtaki mukavemet değerine göre dayanımının yaklaşık \%25'ini kaybetmiştir.

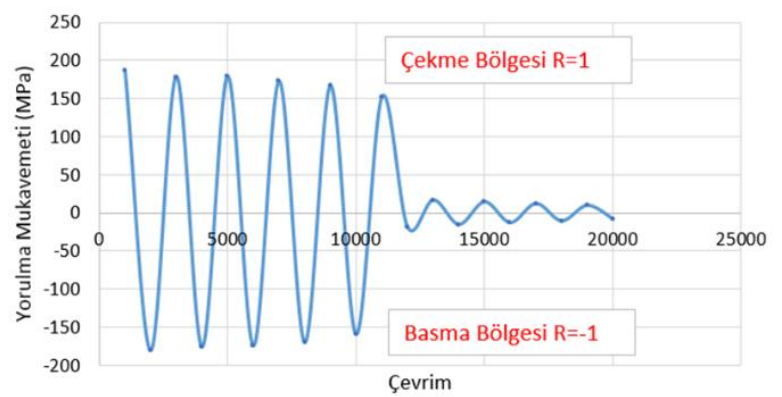

(a)

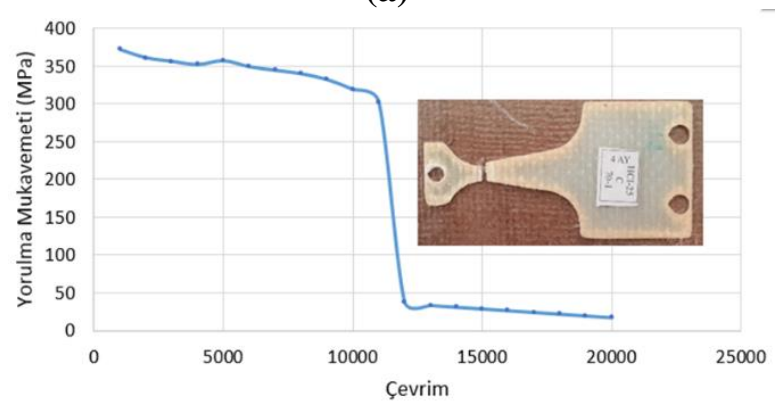

(b)

Şekil 12. Statik mukavemetinin \%80'in de yorulmaya zorlanan test numunesi (a) çeki ve bası bölgesindeki ve (b) toplam yorulma dayanımı değişimi

Şekil 12 'de numuneyi yormaya zorlayan gerilme değeri büyük olduğu için numunenin rijitlik kaybı çok daha rahat gözlemlenebilmiştir. Öyle ki test numunesi her 1000 çevrim için yorulma mukavetinin yaklaşık \%5-6'sını kaybettiği tesbit edilmiştir. Şekil 12(a) çekme ve basma bölgesinde benzer yorulma davranışlarının olduğunu göstermektedir. 11000 çevrime gelindiğinde numune dayanımın kaybederek kırılma meydana gelmiştir (Şekil 12(b)).

Şekil 13'de Belingardi ve Cavatota'nun (Belingardi ve Cavatorta, 2006) yapmış olduğu çalışmadan alınan (Şekil 13(a)) ve geliştirilen cihaz kapsamında elde edilen (Şekil 13 (b)) cam/epoksi tabakalı kompozitlere ait gerilme genliği (rijitlik kaybı)-yorulma ömrü değişim grafiği karşılaştırmalı olarak verilmiştir. Yorulma ömür değerlerindeki farklılık test numunelerinin aynı mekanik dayanımlara sahip olmamasından kaynaklanmaktadır. Fakat her iki grafik içinde gerilme genliği ile yorulma ömrünün ters orantılı olduğu söylenebilir.

Rijitlik kaybı eğrisini elde etmek için 5 farklı gerilme genliğinini her biri için 5 adet numune test edilmiş olup, toplamda farklı genliklerde 25 adet test yapılmıştır. Statik 3 noktalı eğmeli gerilme genliğinin $\% 80-\% 70$ seviyesinde test edilen numunlerin birçoğunun kırıldığ 1 , bunların altında kalan gerilme seviyelerinde ( $\% 60, \% 50$ ve\%40) kırılmadan ziyade yorulma bölgelerinde delaminasyan ve çeşitli matris çatlaklarının olduğu gözlemlenmiştir.

Fiber takviyeli kompozit malzemeler için tipik rijitlik hasarı Şekil-14(a)'da görülmektedir (Sakin, 2015; Van Paepegem ve Degrieck, 2002). Grafikteki 3 bölgeye ayrılırsa; ilk bölgede (Stage I) hızlı bir rijitlik azaltması meydana gelir. $\mathrm{Bu}$ bölgede numunede \%2-5 seviyesinde hızlı bir rijitlik kaybı yaşanır. Bu rijitlik kaybına enine uzanan matris çatlakları sebep olmaktadır. Orta bölgede (Stage II) rijitlik azalması, çevrim sayısına bağlı olarak doğrusal bir şekilde ortaya çıkar. Burda meydana gelen rijitlik kaybı \%1-5 seviyelerindedir. Ayrıca bu bölgede delaminasyonlar ve boyuna matris çatlakları gelişir. Son bölge (Stage III) rijitlik azalması ani adımlarla gerçekleşir ve numunenin kırılması ile sonlanır. 


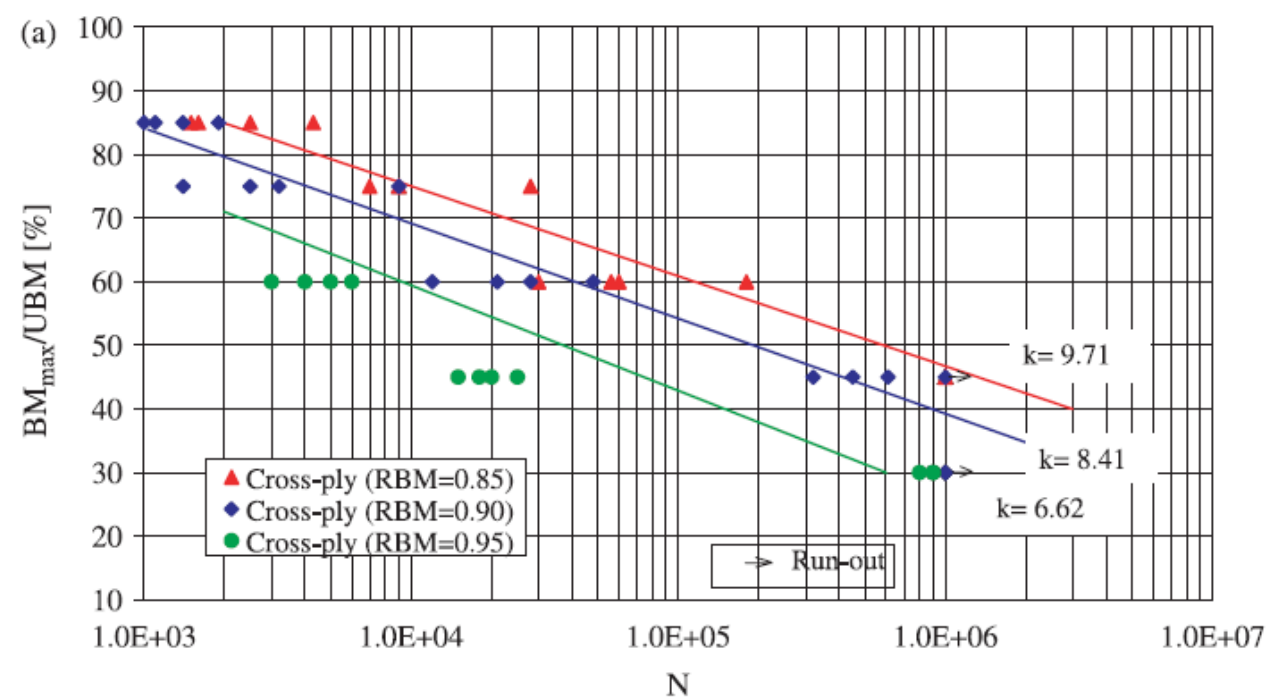

(a)

\section{Genlik-Ömür}

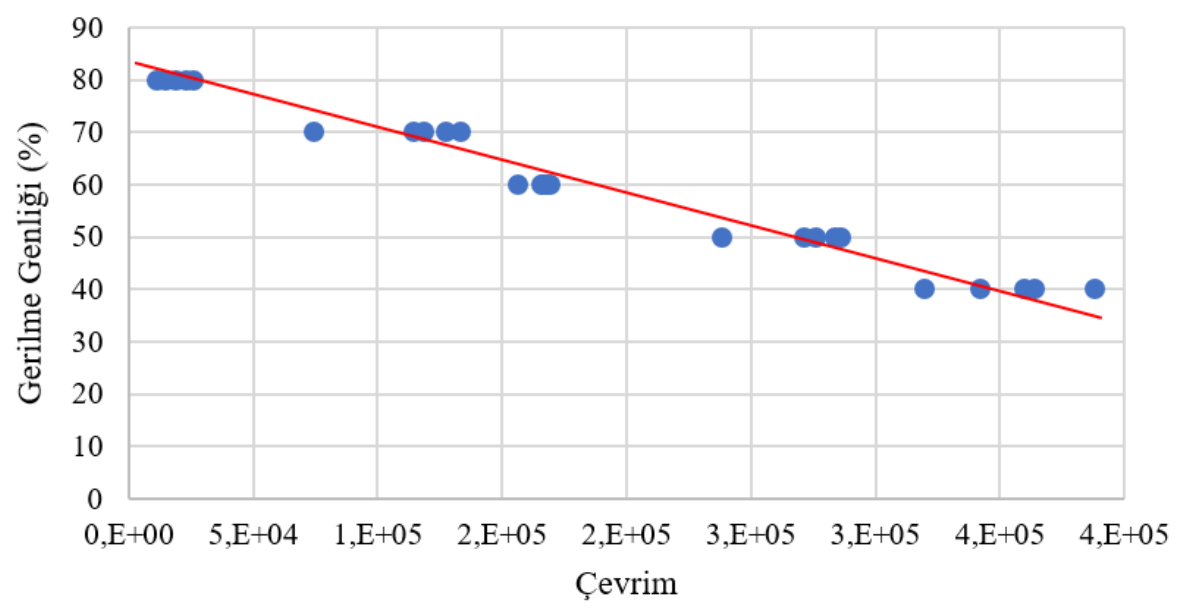

(b)

Şekil 13. Cam/epoksi tabakalı kompozitin genlik-ömür davranışı (a) Belingardi ve Cavatota (Belingardi ve Cavatorta, 2006), (b) testlerden elde edilen

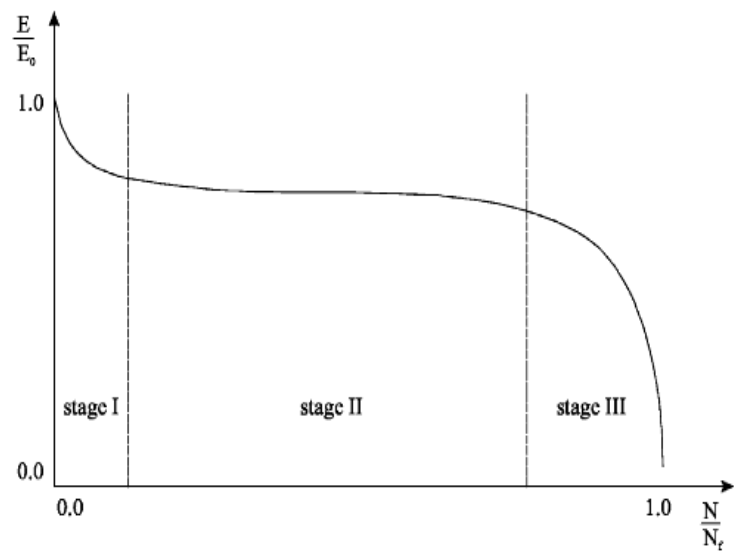

(a)

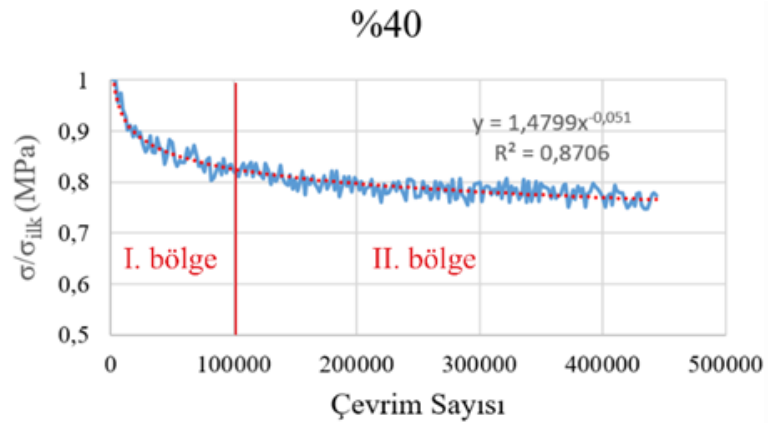

(b) 


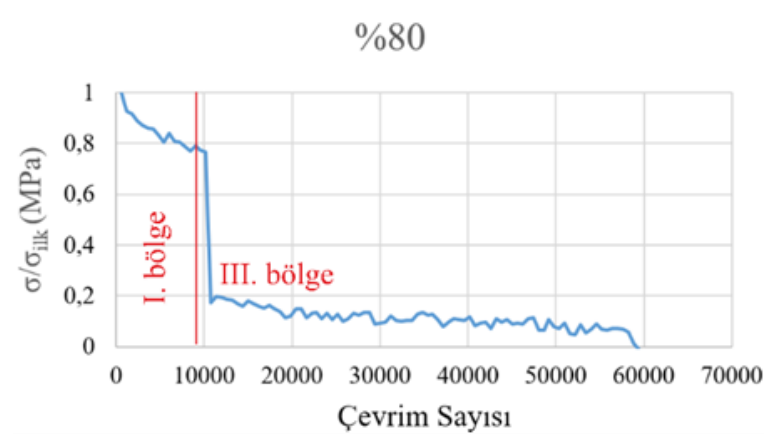

(c)

Şekil 14. Fiber takviyeli kompozit malzemeler için tipik rijitlik hasar eğrisi karşılaş̧ırılması (a) Literatürden alınan cam/epoksi numuneye ait rijitlik değişimi (Van Paepegem ve Degrieck, 2002), (b) $\% 40$ ve (c) $\% 80$ gerilme genliklerinde yüklenen cam/epoksi numuneye ait rijitlik değişimleri

Şekil 14 (b)'de $\% 40$ ve $\% 80$ gerilme genliğinde yüklenmiş numunelerden elde edilen rijitlik kayıplarıgösterilmiştir. \%40 genlikte zorlanan numunenin rijitlik kaybına bakıldığında I. bölge ve II. bölgenin elde edildiği görülmektedir. Yapılan testler kapsamında \%20'lik rijitlik kaybı hasar kriteri olarak değerlendirildiği için numunede \%20'lik rijit kaybı tespit edildiğinden deney yazılım tarafından sonlandırılmıştır. $\mathrm{Bu}$ sebeple \%40'l1k gerilme genliğinde zorlanan numunelerin rijitlik kaybı grafiklerinde III. bölge meydana gelmemiştir. Eğer deney çok uzun süre devam ettirilseydi III. bölgeyi de görmek mümkün olabilirdi. $\% 80$ gibi yüksek gerilme genliklerinde rijitlik kaybı çok hızlı meydana geldiği için II. bölge çok kısa bir çevrim sayısında meydana gelmektedir. Performans testlerimizde her 1000 çevrimde bir veri alındığ 1 için rijitlik kaybı grafiklerinde II. bölge tespit edilememiş̧ir. Fakat hızlı rijitlik kaybından dolayı deney numunesi kırıldığı için III. bölge gözlemlenmiştir.

Şekil 13 ve Şekil 14 literatürdeki yapılan çalışmalardan elde edilen sonuçlar ile performans testlerinden elde edilen sonuçlar karşılaştırılmış ve detayları anlatılmış ve sonuçların uyumlu olduğu görülmüştür.

\section{Sonuçlar ve Değerlendirme}

$\mathrm{Bu}$ çalışmada polimer esaslı levhalar, ahşap ve hafif metalik levhaların yorulma davranışlarını karakterize eden S-N eğrilerini elde etmek için orijinal bir ankastre tipi eğilmeli yorulma test makinesi geliştirilmiştir. Bu kapsamda literatürde daha önce yapılan çok numuneli yorulma test cihazlarından farklı olarak anlı yorulma test parametrelerin gözlenip kontrol edilebildiği kullanışlı bir ara yüze sahip olan ve yorulma test makinasını internet erişimi olan her yerden kontrol etmeyi sağlayan bir yazılım geliştirilmiştir. Servo motorundan aldığ 1 hareketle deplasman kontrollü yorulma testini $0,1-10 \mathrm{~Hz}$ aralığında yapabilmektedir. Malzemenin akma mukavemetinin altındaki değişken yüklerde yapilan yorulma testleri uzun sürmektedir. Geliştirilen ankastre tip eğilmeli yorulma cihazı aynı anda on adet numuneyi test edebildiğinden toplam test süresi on kat azalmaktadır.

E-cam/epoksi tabakalı kompozit numuneler kullanılarak gerçekleştirilen kalibrasyon testlerinden elde edilen sonuçlar gerilme genliği arttıkça yorulma ömrünün azaldığını buna karşın yorulma mukavemetinin arttığını göstermiştir. Her bir test numunesine ait sensörlerden alınan yorulma verileri literatürdeki benzer çalışma sonuçları ile kıyaslandığında yorulma hasar mekanizmasının ve yorulma davranışlarının benzer olduğu görülmüştür.

\section{Teşekkür}

Bu çalışma Uşak Üniversitesi Bilimsel Araştırma Projeleri tarafından desteklenmiştir (Proje No: UBAP012014/MF013).

\section{Kaynaklar}

Abo-Elkhier, M., Hamada, A.A., ve Bahei ElDeen, A., 2014. Prediction of fatigue life of glass fiber reinforced polyester composites using modal testing. International Journal of Fatigue, 69, 2835 .

ASTM D671-93. (1993). Standard Test Method for Flexural Fatigue of Plastics by Constant-Amplitude-of- Force. ASTM International.

ASTM D7264/D7264M - 07. (2015). Standard Test Method for Flexural Properties of Polymer Matrix Composite Materials. ASTM International.

Ay, İ., Sakin, R., ve Okoldan, G., 2008. An improved design of apparatus for multispecimen bending fatigue and fatigue behaviour for laminated composites. Materials \& Design, 29(2), 397-402. 
Azzam, A., ve Li, W., 2014. An experimental investigation on the three-point bending behavior of composite laminate. IOP Conference Series: Materials Science and Engineering, 62, 012016.

Babu, B. S., ve Srinivas, P., 2014. Measurement Of Shear Fatigue Strength Of Fiber Glass Epoxy Laminates \& Carbon Chapstan Laminates Using Fatigue Test Rig. Measurement, 4(01). Retrieved from http://www.iosrjen.org/Papers/vol4_issue 1\%20(part-2)/B04120515.pdf

Belingardi, G., ve Cavatorta, M., 2006. Bending fatigue stiffness and strength degradation in carbon-glass/epoxy hybrid laminates: Cross-ply vs. angle-ply specimens. International Journal of Fatigue, 28(8), 815-825.

Ben Zineb, T., Sedrakian, A., ve Billoet, J.L., 2003. An original pure bending device with large displacements and rotations for static and fatigue tests of composite structures. Composites Part B: Engineering, 34(5), 447-458.

Bura, V., ve Dvr, P., 2014. Testing The Flexural Fat1gue Behavior Of E-Glass Epoxy Laminates. Retrieved from http://citeseerx.ist.psu.edu/viewdoc/down load?doi=10.1.1.671.3414\&rep=rep1\&ty $\mathrm{pe}=\mathrm{pdf}$

Degallaix, G., Hassaïni, D., ve Vittecoq, E., 2002. Cyclic shearing behaviour of a unidirectional glass/epoxy composite. International Journal of Fatigue, 24(2), 319-326.

Di Benedetto, H., De La Roche, C., Baaj, H., Pronk, A., ve Lundström, R., 2004. Fatigue of bituminous mixtures. Materials and Structures, 37(3), 202-216.

Di Franco, G., Marannano, G., Pasta, A., ve Mariotti, G. V., 2011. Design and use of a fatigue test machine in plane bending for composite specimens and bonded joints. In Advances in Composite Materials-Ecodesign and Analysis. InTech. Retrieved from http://www.intechopen.com/download/pd f/14311

Filatov, M.Y., 1989. A machine for fatigue testing of composite materials in pure bending. Strength of Materials, 21(4), 554-556.

Foong, C.-H., Wiercigroch, M., ve Deans, W. F., 2006. Novel dynamic fatigue-testing device: design and measurements. Measurement Science and Technology, 17(8), 2218-2226.

George, T., 2004. Development of a novel vibration-based fatigue testing methodology. International Journal of Fatigue, 26(5), 477-486.

Ghielmetti, C., Ghelichi, R., Guagliano, M., Ripamonti, F., ve Vezzù, S., 2011. Development of a fatigue test machine for high frequency applications. Procedia Engineering, 10, 2892-2897.

Hoefnagels, J.P.M., Kolluri, N., Thissen, M. H.L., van Dommelen, J.A.W., ve Geers, M. G. D., 2008. Advanced miniature mixed mode bending setup for in-situ interface delamination characterization. In Proceedings of the 11th International Congress and Exhibition on Experimental and Applied Mechanics, 2, 5. Retrieved from

https://pure.tue.nl/ws/files/3532018/9558 88596820578.pdf

Kolluri, M., Thissen, M.H.L., Hoefnagels, J. P. M., Dommelen, J.A.W., ve Geers, M. G. D., 2009. In-situ characterization of interface delamination by a new miniature mixed mode bending setup. International Journal of Fracture, 158(2), 183-195.

Koricho, E.G., Belingardi, G., ve Beyene, A. T., 2014. Bending fatigue behavior of twill fabric E-glass/epoxy composite. Composite Structures, 111, 169-178.

Lai, F.-M., Yang, S.-H., Wu, J.-H., Hsueh, C.T., Yang, C.-C., Wang, B.-H., ve Lan, C.H., 2011. Development of Fatigue Test System for Small Composite Wind 
Turbine Blades. Procedia Engineering, 14, 2003-2013.

Mini, K.M., Lakshmanan, M., Mathew, L., ve Mukundan, M., 2012. Effect of fibre volume fraction on fatigue behaviour of glass fibre reinforced composite: VOLUME FRACTION ON FATIGUE OF GFRP. Fatigue \& Fracture of Engineering Materials \& Structures, 35(12), 1160-1166.

Mokhtarnia, B., Layeghi, M., Rasouli, S.H., ve Soltangheis, B., 2016. Development of a New Device for Bending Fatigue Testing. Journal of Testing and Evaluation, 44(4), 20140347.

Pach, E., Korin, I., ve Ipiña, J.P., 2012. Simple Fatigue Testing Machine for Fiber-Reinforced Polymer Composite. Experimental Techniques, 36(2), 76-82.

Philippidis, T.P., ve Vassilopoulos, A.P., 2002. Complex stress state effect on fatigue life of GRP laminates.: part I, experimental. International Journal of Fatigue, 24(8), 813-823.

Roudet, F., 2002. Fatigue of glass/epoxy composite in three-point-bending with predominant shearing. International Journal of Fatigue, 24(2-4), 327-337.

Sakin, R., 2015. Relationship between Barcol hardness and flexural modulus degradation of composite sheets subjected to flexural fatigue. Steel and Composite Structures, 19(6), 1531-1548.

Sakin, R., 2016. Fatigue-life estimation and material selection for commercial-purity aluminum sheets. Research on Engineering Structures and Materials.

Sakin, R., ve Ay, İ., 2008. Statistical analysis of bending fatigue life data using Weibull distribution in glass-fiber reinforced polyester composites. Materials ve Design, 29(6), 1170-1181.

Sakin, R., Ay, İ., ve Yaman, R., 2008. An investigation of bending fatigue behavior for glass-fiber reinforced polyester composite materials. Materials \& Design, 29(1), 212-217.

Sakin, R., Kumru, N. ve Ay, İ., 2008. Gerilme-Kontrollü, Çok Numuneli Eğilme Yorulma Test Cihazı Tasarımı ve Kompozitler İçin Uygulama. Proceedings of 12th International Materials Symposium, (12), 531-541.

Selmy, A. I., Azab, N. A., ve Abd El-baky, M. A., 2013. Flexural fatigue characteristics of two different types of glass fiber/epoxy polymeric composite laminates with statistical analysis. Composites Part B: Engineering, 45(1), 518-527.

Shokrieh, M. M., Esmkhania, M., ve TaheriBehrooz, F., 2014. Fatigue modeling of chopped strand mat/epoxy composites. Structural Engineering and Mechanics, 50(2), 231-240.

Stanzl-Tschegg, S., 2014. Very high cycle fatigue measuring techniques. International Journal of Fatigue, 60, 2 17.

Van Paepegem, W., ve Degrieck, J., 2002. A new coupled approach of residual stiffness and strength for fatigue of fibrereinforced composites. International Journal of Fatigue, 24(7), 747-762.

Waring, G., Hofer, K. E., Brown, I., ve Trabocco, R.E., 1980. Design and operation of multi-specimen fully reversed fatigue systems for advanced composite materials. Experimental Mechanics, 20(5), 153-161.

Wu, J.D., Ho, S.H., Zheng, P.J., Liao, C.C. ve Hung, S.C., 2001. An experimental study of failure and fatigue life of a stacked CSP subjected to cyclic bending. In Electronic Components and Technology Conference, 2001. Proceedings., 51st (pp. 1081-1086).

Xue, H.-Q., Hua, T.A.O., Shao, R.-P. ve Claude, B., 2008. Effect of stress ratio on long life fatigue behavior of Ti-Al alloy under flexural loading. Transactions of 
Nonferrous Metals Society of China, 18(3), 499-505.

Yamamoto, T., Kokubu, A. ve Sakai, T., 2013. Development and several additional performances of dual spindle rotating bending fatigue testing machine GIGA QUAD. In ICF13. Retrieved from http://www.gruppofrattura.it/ocs/index.ph p/ICF/icf13/paper/download/11263/1064 2
Yun, G.J., Abdullah, A.B.M., ve Binienda, W., 2012. Development of a ClosedLoop High-Cycle Resonant Fatigue Testing System. Experimental Mechanics, 52(3), 275-288.

Zaman, W., Li, K., Li, W., Zaman, H. ve Ali, K., 2014. Flexural strength and thermal expansion of 4D carbon/carbon composites after flexural fatigue loading. New Carbon Materials, 29(3), 169-175.. 